\title{
ARENA SOSIAL, PETANI, DAN PERLUASAN KONFLIK PERTANAHAN DI SUMATERA UTARA
}

\author{
Alan Darmawan $\left({ }^{1} *\right)$ \\ ${ }^{1}$ Department of Languages and Cultures of Southeast Asia, Hamburg University, Germany.
}

\begin{tabular}{ll} 
ARTICLE INFORMATION \\
\hline Submitted & $: 04^{\text {th }}$ July, 2020 \\
Review & $: 05^{\text {th }}$ October, 2020 \\
Accepted & $: 01^{\text {st }}$ November, 2020 \\
Published & $: 15^{\text {th }}$ December, 2020 \\
Available Online & $:$ December, 2020
\end{tabular}

KEYWORDS

Arena; dispute; agrarian; peasant; North Sumatra.

\section{CORRESPONDENCE}

*E-mail: alan.darmawan@hotmail.com

\begin{abstract}
A B S T R A C T
This article deals with an agrarian dispute that has expanded from the 'plantation belt' to the swampy area on the East Coast of North Sumatra, which intertwined with a colonial legacy, environmental issue, Masyarakat Adat discourse, and recent political development. I conducted fieldwork in 2014 and periodic visits in 2015 to live among the community, observe, discuss, and document the events that occurred in the periods, and analyze them historically and also in the recent socio-political and economic context. Focussing on a community called Orang Paluh who are mostly the descendants of the explantation labors in Percut residing on the marshland named Paluh Merbau, this research looks at their attempts in dealing with land grabbing, the change of land use, and in negotiating with the restriction in utilizing mangrove trees in their surroundings. In such a social arena of the dispute, Orang Paluh played multiple strategies against land grabbing through mass mobilization, legal dispute, political support from the local political elites, and an alliance with Badan Perjuangan Rakyat Penunggu Indonesia (BPRPI), which holds a mandate as a regional branch of Aliansi Masyarakat Adat Nusantara (AMAN).
\end{abstract}

\section{A. PENDAHULUAN}

A rtikel ini membahas tentang pergumulan komunitas petani dalam sengketa hak atas kepemilikan dan penguasaan sumberdaya alam, dalam hal ini tanah. Tema ini telah menjadi bidang kajian dalam antropologi lingkungan, khususnya dimensi politik dari ekologi, political ecology, dan agensi komunitas lokal menghadapi kekuatan global dan kekuasaan negara (Orr, Lansing, \& Dove, 2015, pp. 160-161). Literatur antropologi untuk kajian tentang kawasan Asia Tenggara menunjukkan pergeseran fokus dari pengetahuan dan adaptasi komunitas dengan lingkungan ke perubahan relasi manusia-sumber daya alam dalam konteks eksploitasi intensif akibat pembangunan infrastruktur, industrialisasi, penggabungan komunitas lokal dengan sistem ekonomi dan politik negara, yang berjalin dengan isu-isu kepemilikan lahan, masyarakat asli, dan dekolonisasi (King \& Wilder, 2012, pp. 369-370; Rudel \& Hernandez, 2017).

Di Indonesia pasca reformasi 1998, kontestasi klaim penguasaan tanah muncul sebagai dampak akumulasi masalah pergeseran hak komunal atas tanah sejak era kolonial, reforma agraria yang tidak berhasil, dan penyingkiran komunitas lokal demi pembangunan ekonomi dan industri. Demokratisasi dan otonomi daerah memberi ruang bagi pemajuan hak-hak komunitas lokal dan rumusan regulasi yang mempertimbangkan hak-hak komunal masyarakat. Dalam konteks ini, ada perubahan dinamika dalam kontestasi penguasaan tanah. Komunitas lokal berperan aktif untuk merevitalisasi wilayah tradisional (Davidson \& Henley, 2007, p. 1). Aktivisme tumbuh sebagai kekuatan dalam upaya klaim hak atas tanah ulayat (Arizona, Wicaksono, \& Vel, 2019; Dhiaulhaq \& McCarthy, 2020), dan/atau untuk memperoleh pengakuan dan perlindungan hak komunal melalui formalisasi hak adat (Afiff \& Rachman, 2019; Bedner \& Arizona, 2019; Robinson, 2019).

Beberapa penelitian terkini menunjukkan kasus spesifik tentang upaya komunitas lokal dalam sengketa penguasaan hutan, tanah, dan sumber daya alam. Penerapan konsep Hutan Nagari sebagai hutan sosial di Kabupaten Solok Selatan, misalnya, dinilai 
tidak sesuai dengan konsep tanah ulayat Alam Surambi Sungai Pagu (Tresno, Ana, Wicaksono, Wicaksanti, \& Deswita, 2018). Di Jawa Tengah, perlawanan komunitas lokal terjadi di sekitar Hutan Lebakbarang, yang melawan agen negara, Perhutani, untuk merebut akses terhadap sumber daya hutan (Fahroji, 2020). Orang Petalangan di sekitar Taman Nasional Tesso Nilo di Riau berkonflik dengan transmigran dan perusahaan perkebunan sawit dalam konteks perubahan fungsi hutan menjadi agro industri perkebunan sawit dan kayu (Yoserizal \& Yesi, 2017). Komunitas Orang Tidung di Pulau Sebatik melakukan klaim atas hutan adat untuk melawan ekspansi penduduk transmigran (Idris, 2017). Sementara itu, Orang Sipori di Papua melawan alih fungsi lahan untuk pembangunan infrastruktur (Frank, Wenehen, \& Idris, 2020).

Sebagaimana menjadi fokus penelitian ini, kiprah komunitas lokal dalam kontestasi penguasaan tanah di Sumatra Utara menunjukkan kompleksitas dan jalinan dengan akar historis. Karl Pelzer menunjukkan akar konflik antara petani lokal Melayu dan Karo dengan kapitalisme perkebunan yang melakukan perluasan areal kebun sejak keberhasilan kebun rintisan pada 1864 (Pelzer, 1978). Migrasi buruh kebun dari daratan Cina, Jawa, dan para pendatang yang menetap di Pesisir Timur ini telah menambah kompleksitas masalah. Hingga lahirnya negara Indonesia, perselisihan hak dan tuntutan atas tanah dari komunitas pendatang berafiliasi dengan partai politik nasional yang mencari dukungan. Distribusi lahan melalui reforma agraria pun terlambat merespon inisiatif warga yang cepat dan spontan (Pelzer, 1982).

Sengketa yang berakar pada kolonialisme ini berakibat konflik panjang dan meluas. Organisasi perjuangan agraria masyarakat Melayu dan Karo, Badan Perjuangan Rakyat Penunggu Indonesia (BPRPI) terlibat konflik dengan perkebunan negara PTPN II (Agustono, Tanjung, \& Suhartono, 1997), yang hingga dewasa ini telah mengurangi secara signifikan ruang hidup orang Melayu Deli (Ikhsan, 2014, 2015). Meskipun mereka menjalankan strategi untuk menciptakan bukti formal untuk melegalisasi hak milik atas tanah ulayat (Khairina \& Lund, 2020), rejim yang berkuasa di setiap periode politik telah menjadikan hak ulayat sebagai 'barang mainan' dalam konteks pluralisme hukum (Ikhsan, 2016).

Komunitas petani keturunan bekas buruh kebun dari Jawa yang bermukim di perbatasan perkebunan, juga terlibat dalam konflik panjang. Di Serdang Bedagai, konflik antara petani Desa Pergulaan dengan PT London Sumatra bermula sejak 1959, yang muncul dalam aksi saling klaim dan kekerasan fisik (Khairina, 2013). Sementara di Desa Pasar VI, Deli Serdang, petani yang juga keturunan bekas buruh kebun terlibat sengketa atas ruang hidupnya yang tergusur akibat pembangunan Bandar Udara Kuala Namu (Kaputra \& Putri, 2020).

Sebagaimana posisi komunitas lokal dalam sengketa agraria di Sumatra Utara, artikel ini membahas tentang upaya komunitas petani, yang sebagian besar adalah keturunan bekas buruh kebun di Percut yang membuka lahan baru di daerah rawa, Paluh Merbau. Artikel ini bertujuan menganalisis perluasan sengketa tanah ke daerah rawa dan para pelaku yang terlibat, unsur yang membentuk konflik, dan tambahan unsur baru akibat desentralisasi politik di Indonesia. Studi ini melihat upaya yang dilakukan oleh petani Paluh Merbau dalam arena sosial yang dibentuk oleh hubungan kompleks pemangku kepentingan seperti negara, politisi lokal dan nasional, aktivis lingkungan, dan agen perusahaan yang mencari lahan. Dalam arena yang berpotensi konflik ini, petani dilihat sebagai pelaku yang turut membentuk, bernegosiasi, untuk mempertahankan, dan mengubah konfigurasi arena demi memperjuangkan kepentingan mereka dalam penguasaan tanah.

\section{B. METODE PENELITIAN}

$\mathrm{F}$ okus penelitian ini ialah kelompok petani yang hidup di daerah rawa seberang muara Sungai Deli dan Sungai Percut, yang nampak seperti pulau rawa dengan hutan bakau. Daerah rawa ini adalah bagian dari Desa Tanjung Rejo (Dusun 11, 12, dan 13), Kecamatan Percut Sei Tuan, Kabupaten Deli Serdang (Gambar 1). Penduduk lokal dan sekitarnya menamai pulau rawa seluas 3400 hektar ini, Paluh Merbau, dan menyebut mereka sendiri secara kolektif, Orang Paluh.

Pengumpulan data berlangsung melalui fieldwork di Paluh Merbau selama enam bulan pertama 2014, dan dilanjutkan dengan kunjungan berkala hingga pertengahan 2015. Penulis melakukan perekaman dari observasi dan perbincangan dengan Orang Paluh dalam pertemuan resmi di Kantor Desa, dan pertemuan-pertemuan warga terkait sengketa tanah dan politik Pemilu. Wawancara dengan tokoh-tokoh desa, pejabat lokal, agen pemerintah di bidang pertanian, aktivis lingkungan, agen perusahaan dan tim kampanye politik Pemilu 2014 juga dilakukan. Dalam proses ini, penulis membuat catatan lapangan, foto, video, serta membaca dokumen seperti laporan statistik, surat tanah, dan peta, untuk melakukan konstruksi masalah yang berlangsung di Paluh Merbau, yang kemudian dianalisis.

Kontekstualisasi bertahap dilakukan untuk melihat jaringan pelaku dalam konteks yang lebih luas seperti politik dan ekonomi kolonial, dan jaringan internasional Non-Government Organizations (NGOs) dalam pelestarian hutan mangrove. Pendekatan ini merujuk pada konsep progressive contextualization untuk menganalisis perubahan tindakan manusia akibat perubahan lingkungan, dan model penelusuran jaringan pelaku secara gradual, dari lokal, nasional, dan global (Tsing, 2005; Vayda, 2009). 


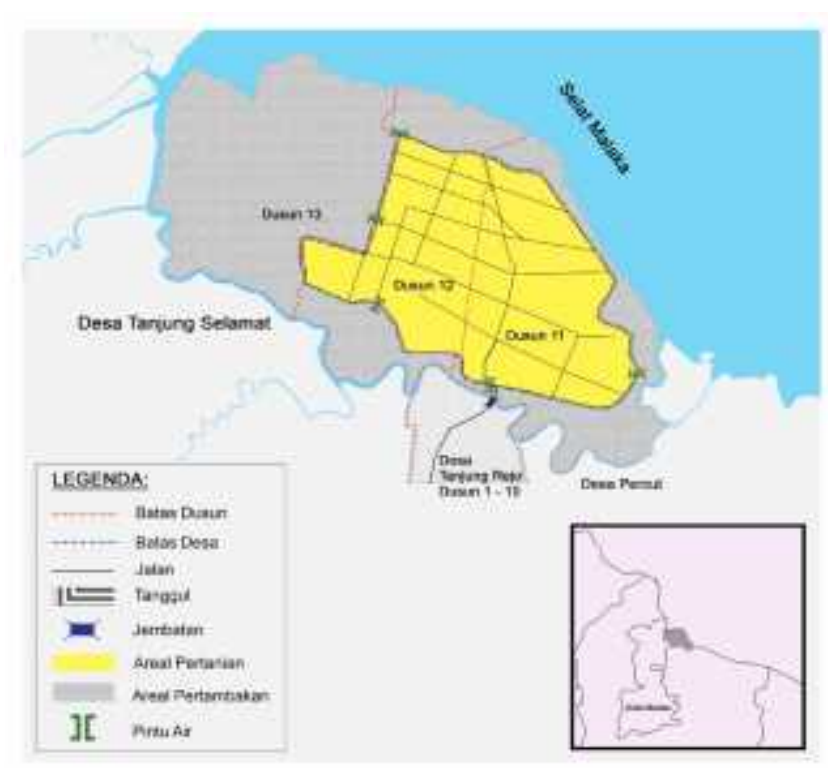

Gambar 1 Peta Paluh Merbau.

Sumber: Peta Penggunaan Lahan, Desa Tanjung Rejo. Dicopy dan diedit oleh Penulis.

\section{HASIL DAN PEMBAHASAN}

\section{Paluh Merbau}

$\mathrm{O}$ rang Paluh masuk ke pulau rawa ini sebagai pekerja upahan yang membuka daerah rawa dalam program ekstensifikasi lahan pertanian yang dimulai sejak 1968. Mereka menyebut kerja itu nebas dan proyek pembukaan lahan itu sebagai Bimas. Sebagian besar pekerja upahan ini adalah keturunan eks-buruh kebun dari Jawa yang bekerja di perkebunan di daerah Percut dan sekitarnya. Dalam siklus seminggu hari kerja, mereka habiskan lima hari untuk mengambil upah, dan dua hari membuka lahan untuk mereka sendiri. Sejak itu, pekerja ini mulai menetap secara bertahap.

Sejak tinggal di Paluh Merbau, komunitas baru ini menghidupi keluarganya dari usaha mencari ikan dan kepiting. Orang Paluh juga bekerja untuk menjaga lahan yang baru dibuka dalam proyek tersebut di atas. Pemilik lahan itu adalah mereka yang memberi upah kepada Orang Paluh untuk membuka daerah rawa, yang sebagian besar adalah pejabat dari Kota Medan dan anggota TNI Angkatan Udara. Para pejabat ini mengorganisasi kelompok-kelompok petani yang berafiliasi dengan partai politik dan Organisasi Islam seperti Persatuan Tani Nahdlatul Ulama (Pertanu) untuk ikut dalam pembukaan lahan.

Pada tahun 1974, Orang Paluh menyaksikan dimulainya proyek pembangunan tanggul yang melingkari daerah rawa Paluh Merbau. Kontraktor dari proyek ini adalah dua perusahaan konstruksi dari Lubuk Pakam (PT. Tobo) dan Stabat (PT. Sinar Langkat), yang masing-masing membawa pekerja dari daerah asal mereka. Proyek dari Kementerian Pekerjaan Umum ini menghasilkan sebuah tanggul sepanjang 17 kilometer yang melindungi 2100 hektar areal pertanian tadah hujan di Paluh Merbau. Air payau di areal pertanian ini mengalir melalui jaringan saluran air dan dibuang melalui lima pintu air yang dibangun pada tanggul. Sekitar 1300 hektar lahan diluar tanggul dibuat menjadi tambak ikan dan udang (lihat Gambar 1).

Sejak awal dibuka, Paluh Merbau hanya bisa dicapai melalui jalur air, anak sungai di muara, yang dalam istilah lokal disebut paluh. Meskipun begitu, penduduk bertambah secara bertahap. Hingga 2015 terdapat sekitar 801 keluarga atau 3402 jiwa, yang terdiri dari sekitar 80 persen orang Jawa eks-buruh perkebunan, 18 persen orang Batak dan Banjar, dan selebihnya adalah orang Melayu. ${ }^{1}$ Sebagian besar mereka datang dari Deli Serdang dan Langkat, dan selebihnya dari berbagai daerah di Pesisir Timur Sumatera Utara. Orang Paluh hidup sebagai petaninelayan dan buruh tambak.

Jaringan listrik masuk ke pulau rawa ini pasca Pemilihan Umum 1997. Orang Paluh mengklaim itu sebagai balas jasa kepada mereka yang telah memenangkan Golongan Karya (Golkar) di tingkat desa. Pasca krisis moneter 1999, Orang Paluh menggunakan dana Jaringan Pengaman Sosial (JPS) untuk membangun jembatan kayu sepanjang 120 meter yang meningkatkan aksesibilitas ke Paluh Merbau. Pemerintah Deli Serdang mengganti jembatan itu dengan jembatan rangka besi pada tahun 2008. Perbaikan infrastruktur jalan meningkatkan mobilitas penduduk dan menambah nilai tanah.

Status tanah di Paluh Merbau tidak pasti. Orang Paluh hanya memegang surat keterangan dari Kepada Desa dan/atau Camat, bukan sertifikat hak milik. Berdasarkan SK Menteri Kehutanan No. 44 Tahun 2005, Paluh Merbau adalah kawasan hutan. Sebagian Orang Paluh, yang menjaga lahan milik para pejabat, menduduki lahan tersebut karena ditinggal pemiliknya. Dengan meningkatnya nilai tanah, para pemilik yang lama mengklaim kembali lahan tersebut dan menimbulkan konflik. Beberapa konflik melibatkan organisasi pemuda paramiliter yang berhadapan dengan Orang Paluh. Selain itu, status yang tidak pasti, daya tarik pembeli tanah, terutama pengusaha dari kota Medan, menyebabkan Orang Paluh menjual tanah yang didudukinya. Hanya sekitar 30 persen lahan di Paluh Merbau yang mereka miliki. Untuk bertani, sebagian besar Orang Paluh menyewa sawah.

Sebagian areal pertanian di Paluh Merbau telah diubah menjadi kebun sawit. Areal di luar tanggul (tambak ikan, udang dan kepiting) dibuat menjadi kolam pemancingan, dan 63 hektar akan dibangun Pembangkit Listrik Tenaga Uap (PLTU) oleh PT. Gregory Energy milik seorang pengusaha energi yang memiliki tambang gas dan batubara di Musi Rawas, Sumatra Selatan serta Kalimantan Timur, Hariara Tambunan (Gambar 2). Orang Paluh semakin waspada akan rumor tentang rencana perluasan kawasan pergudangan Pelabuhan Belawan. Konflik

${ }^{1}$ Sumber: Kantor Kepala Desa Tanjung Rejo, 2015. 
muncul antara Orang Paluh dengan spekulan tanah yang memiliki 'kaki-tangan' di Paluh Merbau, yang merekayasa akta jual beli atas tanah milik beberapa orang warga. Sementara itu, satu perusahaan real estate, PT. Deli Property, membangun beberapa unit rumah dan memulai pemasaran.

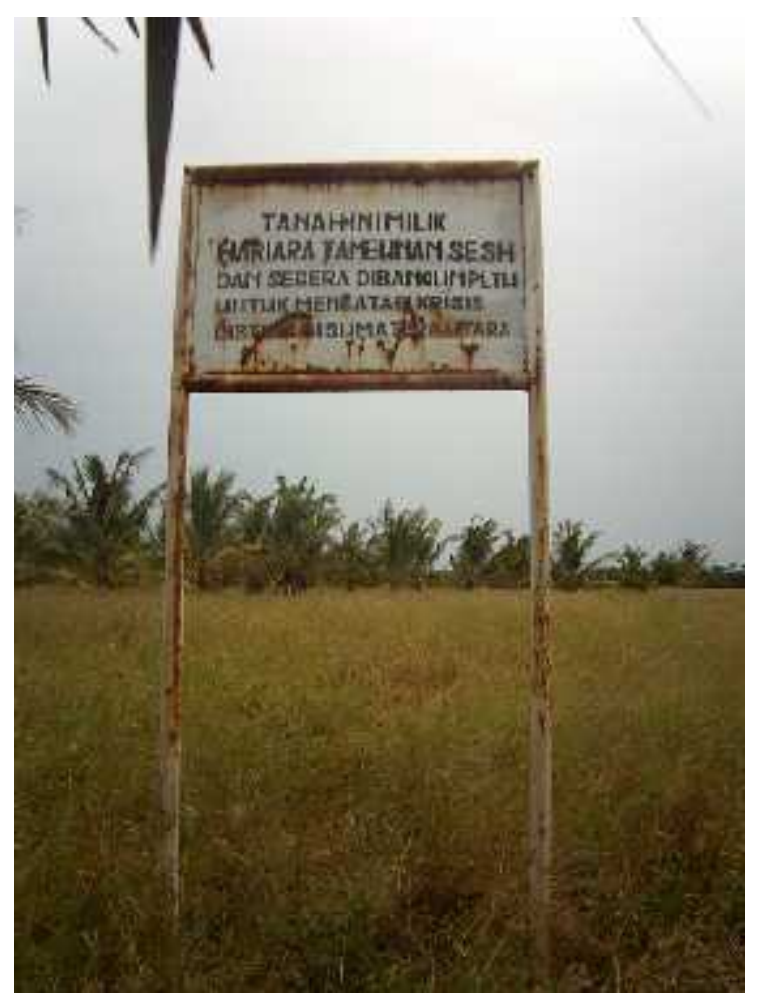

Gambar 2 Tanah Gregory Energy. Foto oleh Penulis.

Di pihak lain NGOs konservasi mangrove dari Kota Medan mengerjakan proyek di Paluh Merbau. Beberapa tahun sejak 2006, Yayasan Akasia Indonesia (YAI) membina kelompok Remaja Mesjid untuk menumbuhkan benih pohon bakau, menanam, dan menjaga habitat burung migran. Yayasan ini juga mendirikan Percut Mangrove Information Centre. Proyek ini didanai oleh Keidanren Nature Conser vation Fund (KNFC) dari Jepang. Sementara, Yayasan Gajah Sumatera (YAGASU) melakukan rehabilitasi hutan mangrove di Paluh Merbau sejak 2007. YAGASU disponsori oleh Planete Urgence dan Livelihoods Funds dari Prancis dalam proyek untuk meningkatan serapan emisi karbon.

Perhatian internasional pada pemanasan global memang menghasilkan proyek konservasi hutan mangrove. Dalam proyek rehabilitasi tersebut, sebagian lahan yang ditanami adalah tambak ikan milik perorangan karena dianggap aman dari terpaan ombak dan perahu nelayan. Namun, Orang Paluh yang awalnya mengambil manfaat dari upah penanaman dalam proyek rehabilitasi mangrove ini, lalu merasakan pembatasan pemanfaatan kayu bakau di sekitar tempat tinggalnya. Pada Februari 2014, seorang pemilik tambak di areal Paluh Getah menebang pohon bakau hasil rehabilitasi, yang mengecewakan pekerja NGO (Gambar 3). Kasus ini menjadi salah satu alasan bagi YAGASU untuk mendorong perumusan dan pengesahan Peraturan Desa tentang Perlindungan Kawasan Mangrove di Desa Tanjung Rejo.

Situasi ini menunjukkan satu konfigurasi sosial yang dirasakan berdampak pada kehidupan warga di Paluh Merbau. Bagaimana arena ini terbentuk dan terkait dengan latar historis sengketa tanah di Pesisir Timur Sumatra Utara? Bagaimana komunitas petaninelayan merespon, bertahan hidup, menolak, atau bernegosiasi dengan perubahan pada tingkat lokal, nasional, bahkan internasional?

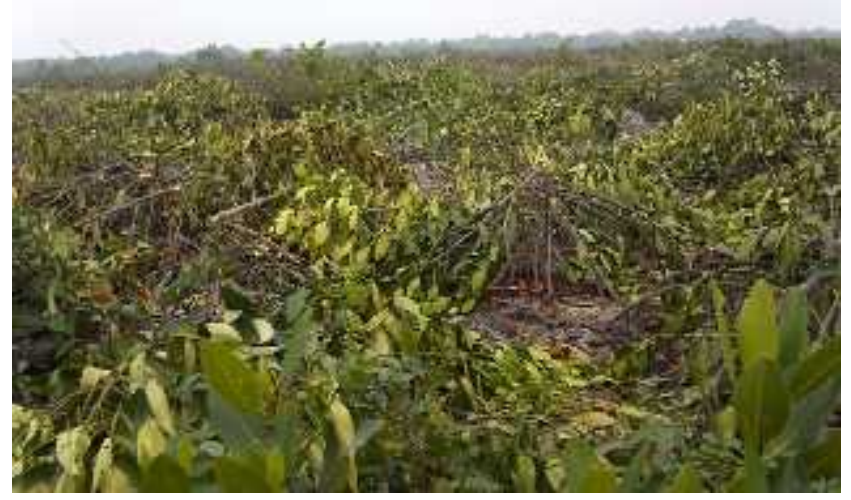

Gambar 3 Penebangan Pohon Bakau di areal Paluh Getah, Dusun 11, Februari 2014. Foto oleh Penulis.

\section{Pembentukan Arena}

Tanah di Paluh Merbau adalah objek sengketa. Arena sosial dibangun dalam kaitannya dengan objek ini oleh diskursus ekonomi, hukum, dan politik, yang membentuk satu konfigurasi sosial. Konfigurasi itu dalam studi ini disebut 'arena sosial' dimana relasi kekuasaan dijalin, strategi dijalankan, untuk mencapai tujuan para pelakunya. Konsep 'arena sosial' merujuk pada teori arena produksi kultural dari Pierre Bourdieu sebagai arena kekuatan (field of force) dan pergulatan (field of struggle) yang cenderung mengubah atau melanggengkan arena pertarungan (Bourdieu, 2012, p. 5).

Arena dikonstruksi oleh ruang posisi-posisi dan ruang pengambilan posisi. Para pelaku menempati posisi-posisi itu, saling berhubungan, dan menjalankan 'strategi', yakni orientasi spesifik praktik yang mengarahkan tindakan. Dalam dinamika relasi ini, para pelaku menempati serangkaian posisi yang silih berganti. Rangkaian posisi itu disebut lintasan, yakni posisi yang mungkin dituju sebagai ganti atas posisi pelaku sebelumnya (Bourdieu, 2012, p. 4). Dalam studi ini, saya melihat posisi petani sebagai pelaku dan pergerakan posisi mereka dalam arena. Struktur internal suatu arena dibentuk oleh relasi kuasa para pelaku dalam bentuk hubungan yang bersifat dominasi, subordinasi, atau ekuivalensi (Jenkins, 2013, p. 125). 
Dalam konteks Paluh Merbau, arena sosial dibentuk oleh hubungan kompleks dan dinamis dalam pertarungan kepentingan para pelakunya. Dari hubungan yang berpotensi konflik ini, konflik yang aktual muncul sebagai kasus spesifik dalam waktu tertentu, baik antara petani dengan aktivis lingkungan, petani dengan orang luar (Medan dan sekitarnya) yang mengklaim tanah di Paluh Merbau, atau petani dengan pengusaha. Studi ini melihat arena sebagai proses sosial yang dinamis dan menelisik satu kasus sengketa Orang Paluh vis-à-vis agen perusahaan.

Selain dibentuk oleh kombinasi hubungan proses internal, sebuah arena juga dibentuk oleh faktor eksternal (Jenkins, 2013, pp. 127-128). Dalam hal ini, perkebunan dan sejarah konflik agraria di Pesisir Timur Sumatera Utara merupakan faktor eksternal turut membentuk arena. Mantan buruh Perkebunan Saentis di sekitar Desa Percut (khususnya kebun Sungai Merah) dan keturunannya adalah orang yang membuka lahan di Paluh Merbau. Mereka mengambil peluang dalam program ekstensifikasi lahan pertanian ke daerah rawa. Mereka berhubungan dengan organisasi masyarakat yang berafiliasi dengan partai politik dan birokrasi, seperti Persatuan Tani Nahdlatul Ulama (Pertanu), sayap organisasi Golkar seperti Gabungan Kerja Rakyat Indonesia (Gakari) dan Kesatuan Tani Indonesia (Ketani), kelompok lokal Petani Nelayan Desa Pantai (PNDP) Percut, dan Persatuan Tani Indonesia (Petani) yang berafiliasi dengan Kesatuan Pejuang Proklamasi (KPP) 1945.

Kelompok pekerja upahan ini bukan kelompok strategis pada awalnya. Namun sejak menduduki Paluh Merbau, mereka memiliki akses terhadap tanah. Identitas sebagai pekerja berganti menjadi petani-nelayan. Faktor politik membentuk identitas petani sebagai suatu kelompok sosial dan politis. Di kancah politik desa, Orang Paluh memenangkan Kepala Desa dari kelompok mereka, melawan calon lain di Desa Tanjung Rejo. Kepercayaan diri kolektif meningkat dalam proses demokrasi di tingkat Desa. Pemilihan Umum Legislatif dan Kepala Daerah juga membuka peluang bagi Orang Paluh untuk bernegosiasi dengan para kandidat dalam transaksi antara dukungan suara oleh warga dan dukungan politik oleh para calon anggota legislatif untuk penyelesaian kasus konflik pertanahan. Klaim atas tanah yang didudukinya dan negosiasi dengan pelaku yang lain, seperti aktivis NGO, pengusaha energi, spekulan tanah, dan politisi lokal yang mencari dukungan dalam kancah Pemilihan Umum, menempatkan Orang Paluh sebagai pelaku dalam pembentukan arena sosial.

Relasi kekuasaan sebagai unsur yang terbentuk dalam arena sosial menunjukkan peran komunitas lokal dalam menjalin hubungan dengan struktur yang lebih besar seperti negara. Dalam konteks historis pembentukan arena, relasi-relasi kekuasaan yang terbentuk sepajang sejarah menunjukkan persing gungan komunitas dengan gagasan kemer-dekaan, nasionalisme, demokrasi, dan globalisasi. Kolo nialisme yang masuk ke Pesisir Timur Sumatera Utara, pembentukan negara bangsa, dan proyek pembangunan areal pertanian di daerah rawa, menjadi latar sejarah bagi terbentuknya arena sosial kontestasi hak atas tanah di Paluh Merbau. Di era reformasi yang memberi kesempatan bagi politik lokal, tumbuhnya gerakan konservasi lingkungan, turut membentuk arena di Paluh Merbau di masa kini. Dalam konteks sengketa agraria di Sumatera Timur, arena pertarungan ini merupakan satu dari dampak kolonial, respon komunitas lokal terhadap proses dekolonisasi, serta perluasan sengketa tanah yang semula berada pada lahan perkebunan. Paluh Merbau sebagai objek sengketa baru, lahirnya kelompok petani bekas buruh yang keluar dari kontrol perkebunan, kemudian membentuk arena sosial baru.

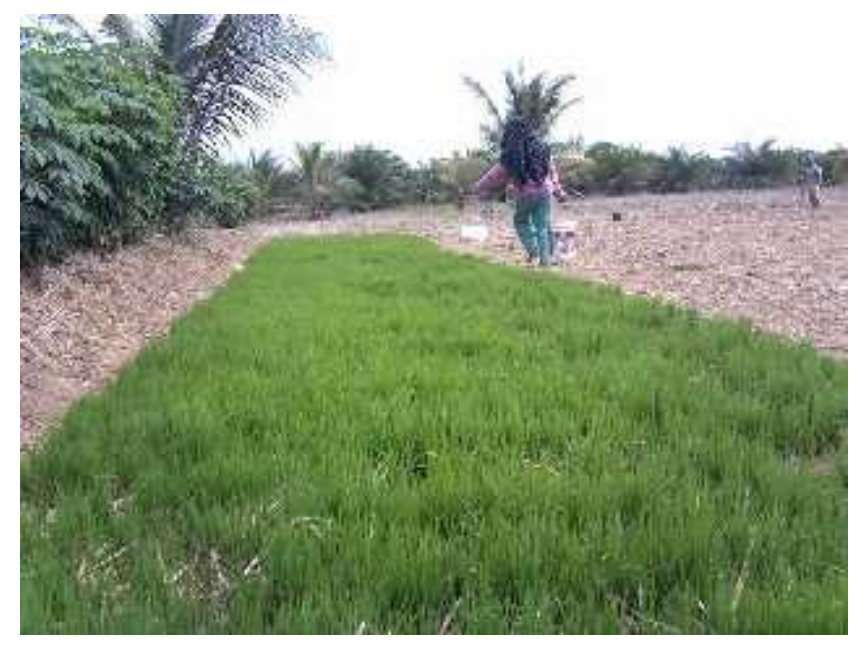

Gambar 4 Pembibitan padi (Januari 2014). Foto oleh Penulis.

\section{Ekspansi Perkebunan dan Peasantization}

Karl Pelzer menggambarkan kondisi awal sengketa agraria di Sumatera Timur, yang cakupannya meluas dari masalah hukum, ekonomi, menjadi masalah politik, dimana kontestasi para pelaku berpaut dengan partai politik nasional dan mobilisasi massa oleh sayap-sayap organisasi di tingkat lokal. Seturut dengan itu, ideologi partai (Nasionalis, Islam, Sosialis, Komunis) yang sedang memungut dukungan politik, menjadi energi bagi pengenalan diri komunitas bangsa yang baru. Partai politik dan komunitas petani menjalin hubungan saling menguntungkan. Perta rungan merebut dukungan, kuasa politik, dan logistik di satu sisi (bagi partai) serta mendapat dukungan politik (bagi kelompok petani), melahirkan kebijakan agraria yang mendua: mempertahankan modal asing, dan membagi sebagian lahan kepada rakyat. Silih bergantinya pejabat dan perubahan kebijakan yang cepat, menambah kusut masalah agraria (Pelzer, 1978, 1982).

Pelzer beranjak dari telaah politik-hukum yang berdampak pada kegaduhan sosial, politik, dan dampak ekonomi di Sumatera Timur. Ann Laura Stoler menyatakan bahwa Pelzer mengabaikan sejarah hubungan kolonial antara buruh dan pekebun 
(Stoler, 1995, p. 18). Sudut pandang makro memetakan sengketa secara luas, namun mengabaikan telaah atas hubungan spesifik yang turut membentuk sejarah agraria. Sebagaimana Clifford Geertz menyatakan bahwa Pelzer menyebut penguasaan oleh militer merupakan "ujung jalan" bagi perusahaan perkebunan asing dalam upaya menyelesaikan masalah agraria (Pelzer, 1982, p. x). "Ujung jalan" bagi pekebun asing ini adalah pangkal bagi bangunan relasi antar pelaku dalam arena yang yang lebih kompleks: negara Indonesia, perkebunan (swasta dan nasional), dan petani (rakyat).

Stoler (1995) membatasi kajian pada gerakan protes, konfrontasi, aksi perlawanan buruh yang muncul, berubah, bervariasi, sebagai konsekuensi hubungan kontradiktif antara korporasi dan resistensi buruh. Stoler membangun asumsinya tentang desain, kontrol, penguasaan, dan respon buruh yang beragam dalam sejarah kapitalisme agraria. la menempatkan konflik dan konfrontasi, kemiskinan, dan ambivalensi (hubungan desa buruh Jawa dengan perkebunan) sebagai ujung yang memilukan. Meminjam konsep Stoler, studi ini justru beranjak dari peasantization, yakni kondisi yang dipertahankan oleh pekebun untuk menciptakan relasi ketergantungan dengan buruh miskin yang menjadi setengah petani (petani pekarangan) untuk memenuhi kebutuhan subsisten, sebagai awal dari kiprah orang yang dipinggirkan. Stoler menggunakan konsep peasantization untuk menunjukkan kondisi yang mendua, menjadi petani tetapi masih berstatus buruh kebun yang dikontrol dan dipertahankan. Dalam studi ini, peasantization dilihat sebagai proses 'menjadi petani' dalam konteks perubahan politik, yang menjadi momentum dimana mantan buruh kebun menegaskan diri sebagai petani. Mereka mencari, menduduki, dan mempertahankan lahan.

Petani Desa Pergulaan, Serdang Bedagai, dan Desa Pasar VI, Deli Serdang (Kaputra \& Putri, 2020; Khairina, 2013), dan petani di Paluh Merbau adalah contoh dari mantan buruh kebun dan keturunannya yang menjadi petani. Dalam konteks Paluh Merbau, ekpansi untuk mencari lahan baru ke daerah rawa dimungkinkan sejak lahirnya kebijakan penguasa Orde Baru untuk ekstensifikasi lahan pertanian. Dalam perkembangan terkini, demokratisasi dan desentraliasi politik telah memberi unsur baru, yakni aspek politik lokal bagi sengketa tanah di Paluh Merbau. Momentum politik, sengketa tanah, dan negosiasi dalam kontestasi politik lokal, mendorong pengenalan diri petani dan posisinya yang kemudian mengarahkan praktik dalam arena sosial sengketa pertanahan.

\section{Petani dalam arena sosial}

Petani (sering disebut petani-nelayan) yang menjadi pelaku aktif dalam arena sosial di Paluh Merbau adalah petani yang mengambil keputusan, perhitungan, dan pertaruhan dalam mempertahankan hidup dalam ketidakpastian dan perubahan. Sejak bekerja membuka areal Paluh Merbau, mereka memilih untuk menetap di atas tanah yang belum jelas statusnya. Dengan kondisi lahan berawa yang tidak mendukung usaha pertanian, mereka menjadi nelayan musiman. Setelah tanggul yang mengelilingi

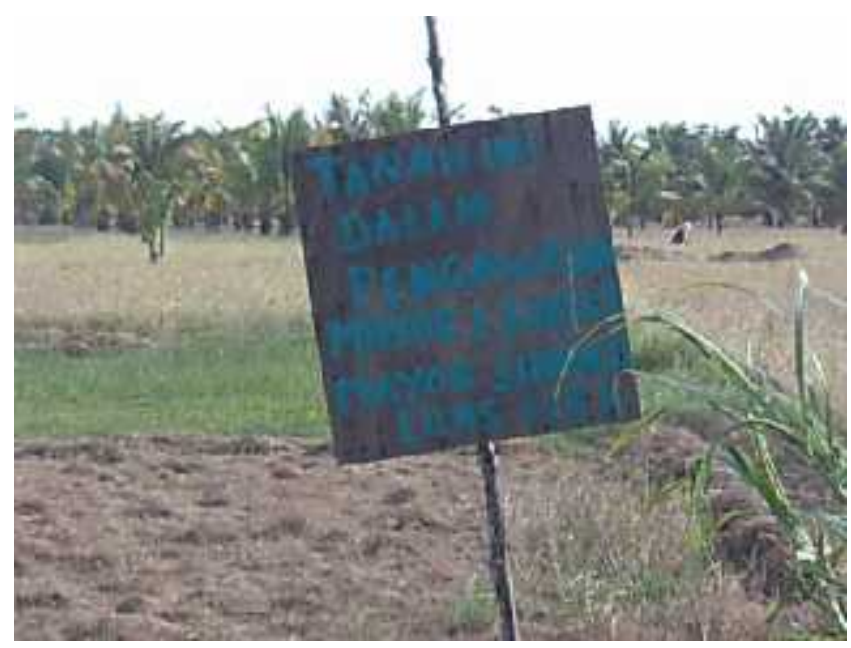

Gambar 5 Areal tanah sengketa 13,8 Hektar. Foto oleh Penulis.

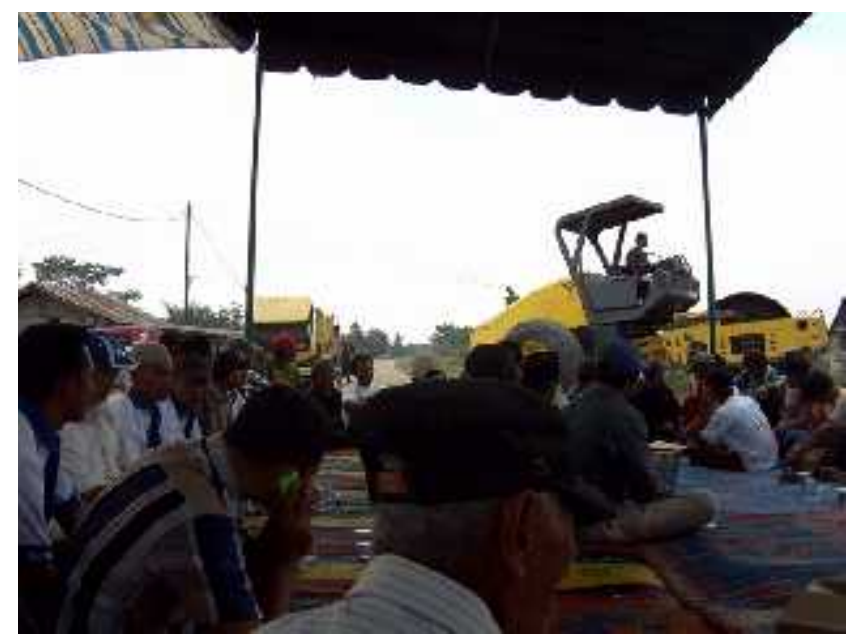

Gambar 6 Acara Tepung Tawar Benih. Beberapa lelaki berbaju putih-biru (kiri) adalah Tim Pemenangan Ismahadi. Foto oleh Penulis.

Paluh Merbau dibangun, terdapat 2100 hektar areal pertanian tadah hujan yang terlindung dari pasang-surut air laut. Dengan masa tanam sekali setahun (November-Maret) tanpa irigasi, para petani melakukan pertaruhan untuk melakukan sekali lagi masa tanam tambahan dimana curah hujan lebih rendah, yang mereka sebut pentongan (AgustusOktober) (Gambar 4). Kegagalan dan keberhasilan pertanian menjadi hal yang tidak menentu.

Sehubungan dengan sengketa tanah yang terus berlangsung, petani-nelayan ini bertarung untuk kepentingan mereka, bertahan, melawan, menggunakan modal sosial, ekonomi, dan simbolik untuk mempertahankan tanah yang mereka duduki. Menurut Pierre Bourdieu, modal yang diakumulasi kelompok petani termasuk modal sosial dan fisik. la mencontohkan kasus masyarakat petani Kabyle di 
Aljazair, dimana modal perjuangan ialah kekuatan fisik dalam perlawanan yang terkait dengan kemampuan memobilisasi sejumlah orang yang siap bertarung (Bourdieu, 1992, p. 122). Kemampuan mobilisasi ini berhubungan dengan modal simbolik, misalnya kepemimpinan.

Relasi dalam arena pertarungan merupakan relasi kuasa yang menggunakan modal. Kekuasaan berbentuk jamak dan bersifat relasional, intrinsik dan hadir di semua relasi sosial, dan dilaksanakan pada titik-titik relasi yang tidak seimbang, tidak terkira jumlahnya, dan dalam bentuk yang beragam (Ritzer \& Smart, 2011, pp. 650-651; Zuska, 2008, p. 27). Michel Foucault menjelaskan:

Power is relations; power is not a thing, it is a relationship between two individuals, a relationship which is such that one can direct the behaviour of another or determine the behaviour of another (Foucault, 1997, p. 155).

Jadi, kekuasaan muncul dalam relasi untuk mengarahkan tindakan orang lain. la dijalankan dalam perilaku atau tindakan. Dalam theory of practice, Bourdieu membangun kerangka berpikir relasional, yang menurutnya memiliki logika sendiri, 'logika praktik', yang tidak mesti sesuai, atau bahkan bertentangan dengan nalar logis. Sebagaimana dikatakan, "practice has a logic which is not that of the logician...the idea of practical logic, 'a logic in itself" without conscious reflection, is a contradiction in terms which defies logical logic" (Bourdieu, 1992, pp. 86 \& 92). Dengan 'logika praktik' inilah para pelaku mengarahkan kemampuan bertindaknya (agency). Untuk melihat 'logika praktik' bekerja dalam 'arena sosoal' di Paluh Merbau, kita akan melihat satu kasus sengketa tanah yang memuncak pada 2014, yang berkembang dan berjalin kelindan dengan politik Pemilihan Umum dan gerakan perjuangan masyarakat adat.

Sengketa ini bermula dari pengukuran lahan pertanian seluas 13,8 hektar oleh pengusaha dari Jakarta, Ahcuan alias Bengkiong, ${ }^{2}$ yang mengklaim telah membeli lahan tersebut dari seorang warga Paluh Merbau, Linawati. Para petani yang merasa tidak terlibat dalam proses jual beli, melakukan protes karena tanahnya termasuk dalam areal yang diukur itu. Rapat-rapat warga dilakukan secara intensif untuk merancang sebuah gugatan hukum. Kepala Desa dipojokkan karena dianggap menyetujui dan mengesahkan jual beli antara Linawati dan Ahcuan, yang dianggap warga sebagai persekongkolan. Tim Hukum dibentuk untuk bersengketa di jalur hukum. Ahcuan, dengan akta jual beli dan surat keterangan Kepala Desa, melawan warga dengan surat keterangan Kepala Desa pula. Pertarungan nampak seimbang secara formal, namun Ahcuan memiliki modal ekonomi dan mengaku mendapat back-up dari aparat keamanan (Gambar 5).

\footnotetext{
${ }^{2}$ Belum ada nama perusahaan. Kepemilikan tanah masih atas nama pribadi Bengkiong.
}

Sementara gugatan berjalan, Ahcuan mempekerjakan pengawal untuk menjaga tanah sengketa dan menghalangi petani yang hendak masuk. Warga melawan dan berkelahi dengan pengawal. Kekerasan memuncak dan Ahcuan meminta bantuan dari anggota marinir, yang datang ketika perkelahian telah dilerai oleh polisi. Kasus kekerasan ini kemudian ditangani oleh kepolisian sebagai perkara pidana. Kepala Desa semakin terpojok dalam sengketa ini. la berusaha meyakinkan warga bahwa ia tidak terlibat dalam persekongkolan, tidak sadar dalam menandatangani akta jual beli, dan mengaku terkena hipnotis. Pembelaan Kepala Desa terdengar tidak logis, tapi ia bekerja sebagai 'logika praktik' dalam arena. Sebagian warga melakukan mobilisasi massa, demonstrasi ke rumah Kepala Desa dan mengancam akan membakar rumahnya.

Sengketa di jalur hukum berjalan tanpa ujung yang jelas. Warga pun melakukan lobi politik. Pada waktu itu, Pemilu Legislatif 2014 memasuki masa kampanye. Calon legislatif DPR-RI, DPRD Provinsi dan DPRD Kabupaten, masuk ke Paluh Merbau untuk mencari dukungan. Warga bernegosiasi untuk memberi suara dan memperoleh dukungan untuk penyelesaian sengketa tanah dan perkara pidana. Beberapa calon legislatif (DPRD Sumatera Utara dan Deli Serdang) dari PDI-Perjuangan, Partai Demokrat, Partai Persatuan Pembangunan, dan Partai Bulan Bintang, diundang ke Paluh Merbau. Dalam pertemuan tertutup dengan para calon legislatif, warga memaparkan kasus sengketa, menjanjikan dukungan, lalu mengambil hadiah dari para calon, seperti $t$-shirt, jilbab, tikar, dan uang. Proses lobi ini bergulir, berkembang, dan menjadi panggung belakang dari kampanye politik terbuka.

Masa bercocok tanam akan dimulai. Kelompok petani biasanya membuat acara Tepung Tawar Benih, berupa membaca doa dan makan bersama, lalu menentukan hari yang tepat untuk turun ke sawah. Pada awal tahun 2014 ini, petani Paluh Merbau bernegosiasi dengan seorang calon anggota DPRD Deli Serdang, Ismahadi, dari Partai Demokrat untuk membantu penyelesaian sengketa melawan Ahcuan dan pendanaan acara Tepung Tawar. Ismahadi membantu logistik kegiatan dan membuka acara secara resmi. Pada saat acara berlangsung (pidato sambutan, doa, makan siang bersama), Ismahadi menunjukkan kepada warga bahwa ia membantu pengerasan jalan. Dump truck membawa batu hilir mudik melewati lokasi acara menuju lokasi pengerasan jalan (Gambar 6).

Di tengah sengketa yang melebar ini, peluangpeluang politik tetap harus diambil. Pemilik Gregory Energy, Hariara Tambunan, yang menjadi calon anggota DPR-RI, datang ke Paluh Merbau untuk mencari dukungan. Sebelumnya, Tim Pemenangan Hariara telah mewakilinya untuk memberi dukungan materil dan berkampanye di acara Tepung Tawar Benih. Tapi kali ini, Hariara datang langsung untuk berdialog. Warga menjanjikan suara dan dukungan moral atas pembangunan PLTU di Paluh Merbau, yang dikatakan untuk "mengatasi krisis listrik di 
Sumatera Utara". Tim Pemenangan Hariara mengabarkan bahwa seorang investor dari Korea Selatan bersedia untuk berinvestasi. Setelah jual beli lahan dari warga kepada Hariara Tambunan yang dikatakan, berjalan mulus, pembangunan PLTU masih tertunda pengurusan AMDAL. Warga menyimpan harapan mendapat pekerjaan dari PLTU apabila dibangun nanti. Dalam konteks ketidakpastian sengketa, harapan akan pekerjaan yang lebih baik, dan dampak lingkungan yang belum diketahui, dukungan warga untuk kemenangan Hariara bersifat transaksional.

Di lain pihak, Orang Paluh bersekutu dengan organisasi perjuangan agraria. Badan Perjuangan Rakyat Penunggu Indonesia (BPRPI) dipimpin oleh Harun Nuh (2013-2018) masuk ke Paluh Merbau untuk membentuk satu cabang organisasi itu. Kelompok petani yang bersengketa menyambut kedatangan BPRPI. Dalam satu pertemuan, Harun Nuh menjelaskan posisi Paluh Merbau:

"....sebagai bagian dari hak adat rakyat penunggu yang berhak atas tanah jaluran. Pada tahun 1951, Pemerintah Indonesia menghapus tanah jaluran. Sekelompok orang Melayu dan Karo mendirikan BPRPI pada 1953 dan menuntut hak atas tanah jaluran. Tahun 1975, Gubernur Sumatera Utara memberikan Paluh Merbau dan Paluh Kurau (di Hamparan Perak, Deli Serdang) sebagai ganti tanah jaluran. Jadi Paluh Merbau adalah hak adat dan cabang BPRPI harus berdiri di sini."

Narasi Harun Nuh menjadi modal kultural bagi petani di Paluh Merbau. Tanah jaluran, yang awalnya diberikan pekebun tembakau Belanda sebagai ganti tanah cadangan untuk rakyat dari raja Melayu seluas 4 bahu (2,8 hektar) per keluarga, dihapuskan pada 1951 (Pelzer, 1982, p. 111) dan BPRPI berdiri tahun 1953. Cerita dari Harun adalah tradisionalisasi Paluh Merbau, menghubungkannya dengan masa lalu untuk melegitimasi klaim. ${ }^{3}$ Seorang perintis Paluh Merbau yang dihormati, Kek Misno, tahu sebagian dari kisah orang Melayu di daerah rawa ini, dimana:

"BPRPI tidak menerima tanah rawa sebagai ganti jaluran karena tidak layak untuk pertanian. Sebagian orang Melayu yang menerima, membentuk organisasi Ikatan Keluarga Deli (IKD) dan Ikatan Keluarga Serdang (IKS), dan menduduki Paluh Merbau pada saat yang bersamaan dengan pembukaan daerah rawa ini, pada saat kerja nebas berlangsung. Namun anggota IKD dan IKS tidak bertahan lama dan pergi dari Paluh Merbau“.

Konteks pada tahun 1970an adalah BPRPI secara simbolik menyerahkan tanah jaluran kepada pemerintah Sumatera Utara sebagai ungkapan ketidakpercayaan akan adanya jalan penyelesaian. Namun pemerintah memberikan ganti tanah jaluran di Paluh Merbau yang mengakibatkan perpecahan di

\footnotetext{
${ }^{3}$ Konsep tradisionalisasi dalam antropologi linguistik dan pertunjukan merujuk pada upaya untuk menghubungkan sebuah praktik atau diskursus dengan masa lalu (Bauman, 2012, pp. 109-110).

253 | P a g e

https://doi.org/10.25077/jantro.v22.n2.p246-255.2020
}

tubuh BPRPI dan terbentuknya IKD, IKS, dan IKL (Langkat) (Agustono et al., 1997, p. 92). Meskipun Kek Misno memiliki cerita yang berbeda dengan Harun, ia mendukung pembentukan BPRPI di Paluh Merbau dan menjadi salah satu penasihat. 'Logika praktik' mengarahkan tindakan Kek Misno untuk menggalang aliansi dan menambah modal sosial dalam sengketa melawan Ahcuan. Sementara itu, klaim historis BPRPI atas tanah adatnya, meluas ke Paluh Merbau. Unsur baru menambah kompleks sengketa. Transaksi politik belum mendapat hasil. Sengketa masih berjalan walau ketegangan mereda sementara. Persekutuan tetap harus dijalin, dan ketidakpastian diperpanjang lagi. Dalam situasi ini Orang Paluh harus tetap bertani, menangkap ikan, udang, dan kepiting. Konflik memang mereda, tapi arena masih tetap digelar.

\section{KESIMPULAN}

S engketa agraria di Sumatra Utara meluas ke daerah rawa, semakin kompleks, seiring dengan perkembangan ekonomi dan politik. Dalam konteks ini, Orang Paluh turut membentuk konfigurasi arena sosial, menjalankan strategi memperkuat klaimnya dengan mobilisasi masa, menempuh jalur hukum, dan beraliansi dengan gerakan adat.

\section{E. UCAPAN TERIMAKASIH}

A rtikel ini ditulis berdasarkan hasil penelitian etnografi untuk tesis pada Program Studi Magister Antropologi Sosial, Universitas Negeri Medan yang dipertahankan pada Juli 2014. Saya mengucapkan terima kasih kepada guru, teman, dan informan, khususnya pembimbing akademik (Dr.phil. Ichwan Azhari dan Dr. Hidayat), para penguji (Dr. Fikarwin Zuska, Dr. Deny Setiawan, Dr. Edy Ikhsan), serta warga Paluh Merbau: keluarga Almarhum Kek Wagio, Pak Selamet dan keluarga, Syamsul Bahri dan keluarga, dan Pak Dahrin Pane. Saya haturkan juga terima kasih kepada reviewers dan editor Jurnal Antropologi atas saran dan komentar yang konstruktif.

\section{DAFTAR PUSTAKA}

Afiff, S. A., \& Rachman, N. F. (2019). Institutional Activism: Seeking Customary Forest Rights Recognition from Within the Indonesian State. Asia Pacific Journal of Anthropology, 20(5), 453470.

https://doi.org/10.1080/14442213.2019.1670245

Agustono, B., Tanjung, M. O., \& Suhartono, E. (1997). Badan Perjuangan Rakyat Penunggu Indonesia Vs PTPN II: Sengketa Tanah di Sumatra Utara. 
Bandung: Wahana Informasi Masyarakat dan AKATIGA.

Arizona, Y., Wicaksono, M. T., \& Vel, J. (2019). The Role of Indigeneity NGOs in the Legal Recognition of Adat Communities and Customary Forests in Indonesia. Asia Pacific Journal of Anthropology, 20(5), 487-506. https://doi.org/10.1080/14442213.2019.1670241

Bauman, R. (2012). Performance. In R. Bendix (Ed.), A Companion to Folklore (pp. 94-118). Malden: Wiley-Blackwell.

Bedner, A., \& Arizona, Y. (2019). Adat in Indonesian Land Law: A Promise for the Future or a Dead End? Asia Pacific Journal of Anthropology, 20(5), 416-434. https://doi.org/10.1080/14442213.2019.1670246

Bourdieu, P. (1992). The Logic of Practice. California: Standford University Press.

Bourdieu, P. (2012). Arena Produksi Kultural. Yogyakarta: Kreasi Wacana.

Davidson, J., \& Henley, D. (2007). The Revival of tradition in Indonesian politics: the deployment of adat from colonialism to indigenism. London and New York: Routledge.

Dhiaulhaq, A., \& McCarthy, J. F. (2020). Indigenous Rights and Agrarian Justice Framings in Forest Land Conflicts in Indonesia. Asia Pacific Journal of Anthropology, 21(1), 34-54. https://doi.org/10.1080/14442213.2019.1670243

Fahroji, F. R. (2020). Bergerak dalam Diam: Budaya Penguasaan dan Kontestasi Sumber Daya Hutan Lebakbarang. Antropologi Indonesia, 40(2), https://doi.org/10.7454/ai.v40i2.12243

Foucault, M. (1997). The politics of truth. New York: Semiotext(e).

Frank, S. A. K., Wenehen, A., \& Idris, U. (2020). The land tenure and the land use among supiori in Papua. ETNOSIA: Jurnal Etnografi Indonesia, 5(1), https://doi.org/10.31947/etnosia.v5i1.9924

Idris, U. (2017). 'Belimpun Taka Tugas, Insuai Taka Tapu': Orang Tidung, Marginalisasi dan Perlawanan di Pulau Sebatik Nunukan. ETNOSIA: Jurnal Etnografi Indonesia, 2(2), 134152. https://doi.org/10.31947/etnosia.v2i2.2574

Ikhsan, E. (2014). Communal Land Rights of Malay People in North Sumatera: Power, State and Deulayatisasi. Indonesia Law Review, 2, 358373. https://doi.org/10.15742/ilrev.v4n3.100

Ikhsan, E. (2015). Konflik Tanah Ulayat dan Pluralisme Hukum: Hilangnya Ruang Hidup Orang Melayu Deli. Jakarta: Yayasan Pustaka Obor Indonesia.

Ikhsan, E. (2016). Land Tenure of the Malay People in North Sumatera: From Normative Trap to the Historical Denial. Hasanuddin Law Review, 2(3), 312-327.

https://doi.org/10.20956/halrev.v2i3.316

Jenkins, R. (2013). Membaca Pikiran Bourdieu. Yogyakarta: Kreasi Wacana.
Kaputra, I., \& Putri, P. W. (2020). The Precarity of Peri-urban Resistance: A Resistance to the Forced Eviction of Pasar VI Village and the Development of Kualanamu International Airport, North Sumatera. PCD Journal, 8(1), 49-67. https://doi.org/10.22146/pcd.v8i1.419

Khairina, W. (2013). Konflik Agraria Petani Desa Pergulaan Vs PT. PP. London Sumatera Indonesia Tbk (Kabupaten Serdang Bedagai, Sumatera Utara). Universitas Negeri Medan.

Khairina, W., \& Lund, C. (2020). Creating Legal Facts: Indigenous People versus State Plantation Companies in Medan, Indonesia. PCD Journal, 8(1), 1-12. https://doi.org/10.22146/pcd.v8i1.417

King, V. T., \& Wilder, W. D. (2012). Antropologi Modern Asia Tenggara. Yogyakarta: Kreasi Wacana.

Orr, Y., Lansing, J. S., \& Dove, M. R. (2015). Environmental Anthropology: Systemic Perspectives. Annual Review of Anthropology, 44(1), 153-168. https://doi.org/10.1146/annurevanthro-102214-014159

Pelzer, K. J. (1978). Planter and Peasant: Colonial Policy and the Agrarian Struggle in East Sumatra 1863-1947 (VKI 84). 'S-Gravenhage: Martinus Nijhoff.

Pelzer, K. J. (1982). Planters Against Peasants: The Agrarian Struggle in East Sumatra 1947-1958 (VKI 97). 'S-Gravenhage: Martinus Nijhoff.

Purwanto, S. A., \& Haryono, H. (2019). Dimensi Adat dan Dinamika Komunitas Dayak di Kalimantan Timur. Antropologi Indonesia, 40(1), 67-87.

Ritzer, G., \& Smart, B. (2011). Handbook Teori Sosial. Bandung: Nusa Media.

Robinson, K. (2019). Can Formalisation of Adat Land Regulation Protect Community Rights? The Case of the Orang Asli Sorowako and the Karongsi'e/Dongi. Asia Pacific Journal of Anthropology, 20(5), 471-486. https://doi.org/10.1080/14442213.2019.1670247

Rudel, T. K., \& Hernandez, M. (2017). Land Tenure Transitions in the Global South: Trends, Drivers, and Policy Implications. Annual Review of Environment and Resources, 42, 489-507. https://doi.org/10.1146/annurev-environ-102016060924

Stoler, A. L. (1995). Kapitalisme dan Konfrontasi di Sabuk Perkebunan Sumatera Utara 1870-1979. Yogyakarta: Karsa.

Tresno, T., Ana, R. F., Wicaksono, M., Wicaksanti, A. R., \& Deswita, R. (2018). Antara Ulayat Adat dan Hutan Nagari: Sebuah Kebijakan Perhutanan Sosial Di Minangkabau. Jurnal Antropologi: IsuIsu Sosial Budaya, 20(2), 191-211. https://doi.org/10.25077/jantro.v20.n2.p191211.2018

Tsing, A. L. (2005). Friction: An Ethnogaphy of Global Connection. New Jersey: Princeton University Press.

Vayda, A. (2009). Explaining Human Actions in Environmental Changes. United Kingdom: Alta Mira Press. 
Yoserizal, \& Yesi. (2017). Conflict of Interest Among Stakeholders in Tesso Nilo National Park (TNTP). Jurnal Antropologi: Isu-Isu Sosial Budaya, 19(2), 101-107.

Zuska, F. (2008). Relasi Kuasa Antar Pelaku Dalam Kehidupan Sehari-hari. Medan: Universitas Sumatera Utara Press. 